\title{
Pyrimidine Base Degradation in Cultured Murine C-1300 Neuroblastoma Cells and In Situ Tumors
}

\author{
Mendel Tuchman, Robert F. O'Dea, Margaret L. R. Ramnaraine, and Bernard L. Mirkin \\ Divisions of Metabolism and Clinical Pharmacology, Departments of Pediatrics, Laboratory Medicine \\ and Pathology and Pharmacology, University of Minnesota, Minneapolis, Minnesota 55455
}

\begin{abstract}
Dihydropyrimidine dehydrogenase (DPD), the initial, ratelimiting step in pyrimidine degradation, was studied in two cell lines of murine neuroblastoma (MNB-T1 and MNB-T2) that were derived from C-1300 MNB tumor carried in A/J mice. The MNB-T2 (low malignancy) cell line was originally derived from the in situ tumor and carried in tissue culture for more than 100 passages; the MNB-T1 (high malignancy) line consisted of a new sub-culture that was also established from the in situ MNB tumor. DPD activity was determined in cytosolic preparations of MNB utilizing high performance liquid chromatography to separate the radiolabeled substrate $\left(\left[2-{ }^{14} \mathrm{C}\right]\right.$ thymine) from $\left[2-{ }^{14} \mathrm{C}\right]$ dihydrothymine. The apparent affinity of DPD for NADPH in MNB cells $\left(K_{\mathrm{m}} \sim 0.08 \mathrm{mM}\right)$ was identical to that of $A / J$ mouse brain and liver. The DPD activity of the high malignancy (MNB-T1) cell line was $14.3 \%$ of that observed in the low malignancy (MNB-T2) line. In situ tumors formed after implantation of high malignancy (MNB-T1) cells into $\mathrm{A} / \mathrm{J}$ mice had only $25.2 \%$ of the DPD activity observed in tumors derived from low malignancy (MNB-T2) cells. When MNB-T2 cells were injected into naive $A / J$ mice, tumors developed in only $68 \%$ of animals, the tumor growth rate was slow and a mortality of $\mathbf{2 0 \%}$ was observed. In contrast, tumors derived from injected MNB-T1 cells showed a faster growth rate and $100 \%$ mortality. Most MNB-T2 derived tumors were not lethal and ultimately resolved while the MNB-T1 derived tumors were invariably lethal. These studies support the concept that the levels of DPD activity in neoplastic cells are inversely related to their malignant expression and also provide a model to study differences between neuroblastoma cell lines derived from the same in situ tumor but which manifest different neoplastic behavior.
\end{abstract}

\section{Introduction}

The investigation of the pyrimidine degradation pathways (Fig. 1) in neoplastic tissues is important because these enzymes may critically regulate the concentration of pyrimidine bases required for DNA and RNA synthesis during cellular proliferation (1). Furthermore, this degradative pathway is also responsible for the catabolism of therapeutically useful pyrimi-

Address reprint requests to Dr. Tuchman, Department of Pediatrics, University of Minnesota, Box 400 UMHC, 420 Delaware Street SE, Minneapolis, MN 55455.

Received for publication 25 June 1987 and in revised form 18 September 1987.

J. Clin. Invest.

(C) The American Society for Clinical Investigation, Inc.

$0021-9738 / 88 / 02 / 0425 / 06 \$ 2.00$

Volume 81, February 1988, 425-430 dine base analogues such as 5-fluorouracil, 5-bromouracil, 5diazouracil, 5-iodouracil, and 5-nitrouracil (2).

The extent of pyrimidine base degradation in hepatoma cells has been extensively studied by Weber et al. (3) who proposd the "molecular correlation concept" theory to explain the inverse relationship between increased pyrimidine "salvage" activity and decreased pyrimidine degradative activity observed in hepatoma cells when compared with normal liver. However, Naguib et al. (4) using modified dihydropyrimidine dehydrogenase (DPD) ${ }^{1}$ assays that were more sensitive and specific than those utilized in the previous study (3), reported that some solid tumors displayed higher activity of pyrimidine degradative enzymes than their nonneoplastic counterparts. This observation suggested that DPD might also act as an anabolic enzyme in some tumor tissues by catalyzing pyrimidine synthesis.

The mechanisms regulating pyrimidine degradation in normal or neoplastic cells remain poorly understood. Although various nucleotides, nucleosides, and bases can modify the activity of DPD in vitro (5) it is unclear whether these factors affect pyrimidine degradative enzymes in vivo. For example, DPD is inactive in the absence of its cofactor NADPH; thus, it is possible that the affinity of this enzyme for NADPH and/or the availability of this cofactor may determine the rate of pyrimidine degradation in vivo.

This investigation has examined the changes in DPD activity and its dependence on NADPH in C-1300 murine neuroblastoma cells (MNB), obtained from tissue culture and from in situ tumors. A new, sensitive and highly specific assay for DPD, which is based on the separation of radiolabeled substrate and its metabolite by HPLC was used.

\section{Methods}

Chemicals. $\left[2-{ }^{14} \mathrm{C}\right]$ Thymine $(55 \mathrm{mCi} / \mathrm{mmol})$ was purchased from Amersham Corp., Arlington Heights, IL. Thymine, dihydrothymine, ureidoisobutyrate, and NADPH were purchased from Sigma Chemical Co., St. Louis, MO.

Animal tissues and in situ MNB tumors. A/J mice, (Jackson Laboratories, Bar Harbor, ME) were injected subcutaneously with suspended $\left(1 \times 10^{6}\right.$ cells) MNB cells in RPMI media. MNB cells were obtained either from 14 to $18 \mathrm{~d}$-old tumors that had been carried in $\mathrm{A} / \mathrm{J}$ mice (MNB-T1) or from confluent MNB cell cultures that were maintained in tissue culture for $>100$ passages (MNB-T2). When MNB tumors had attained a cross-sectional diameter of $1.5-2.5 \mathrm{~cm}$ (2-3 wk after injection), the mice were killed by cervical dislocation.

1. Abbreviations used in this paper: DAH, dihydropyrimidine amidohydrolase; DPD, dihydropyrimidine dehydrogenase; MNB-T1, high malignancy new subcultured cell line established from in situ C-1300 murine neuroblastoma; MNB-T2, low malignancy murine neuroblastoma cell line originally derived from the in situ tumor and carried in tissue culture for more than 100 passages; $2 \mathrm{ME}$, 2-mercaptoethanol; UP, ureidopropionase. 


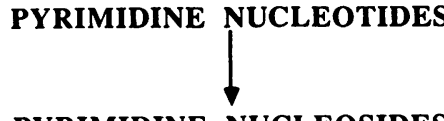

PYRIMIDINE NUCLEOSIDES

PYRIMIDINE BASES

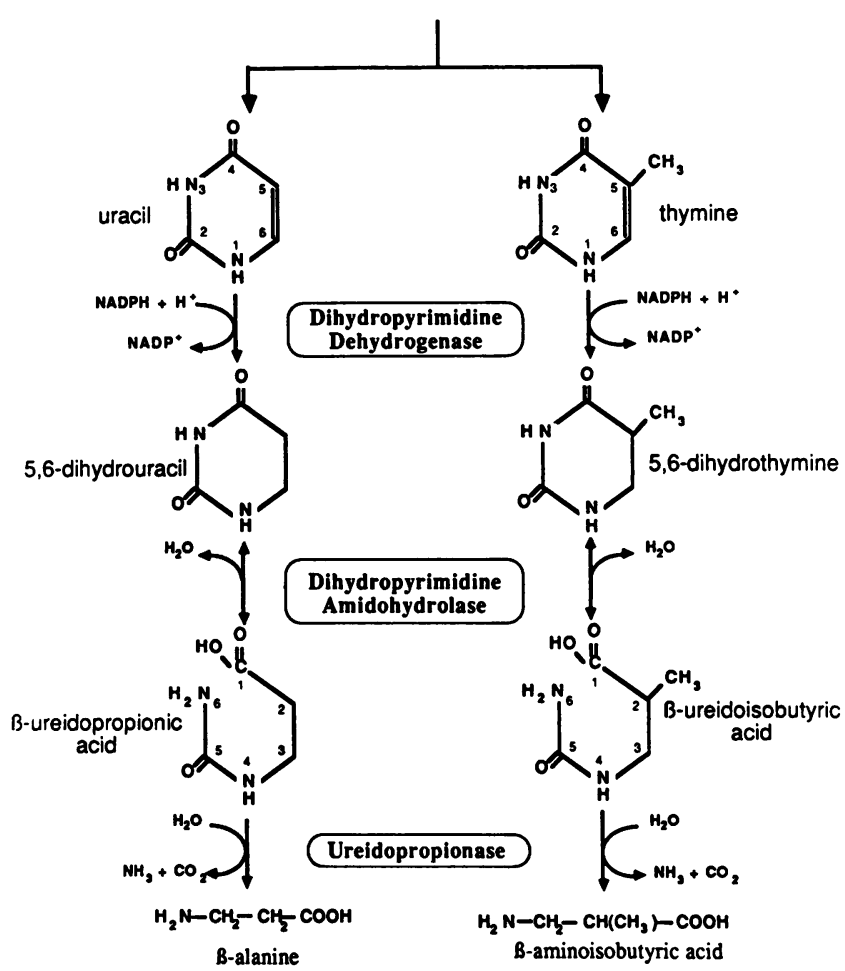

Figure 1. Pyrimidine base degradative pathway. Dihydropyrimidine dehydrogenase (DPD) is NADPH dependent and considered the rate-limiting enzyme. Only DPD activity could be demonstrated in murine neuroblastoma cells.

MNB tumor, brain, and liver tissues were carefully dissected, weighed, and washed with phosphate buffer. The tissues were finely minced in 5 vol of $35 \mathrm{mM}$ phosphate buffer, $\mathrm{pH} 7.4$, containing $2.5 \mathrm{mM} \mathrm{MgCl}_{2}$ and homogenized for $1-2 \mathrm{~min}$ at $4^{\circ} \mathrm{C}$ with a Polytron Tissue-Mizer (Brinkmann Instruments, Westbury, NY). Tissue supernatants were prepared as described below.

Tissue culture. MNB (strain TBJ 734) originally supplied as biopsy specimens by the E. G. and G. Mason Research Institute, Worcester, MA was used to establish the in situ tumor model. This cell line has been continuously maintained by sequential passage in situ and as a tissue culture line in our laboratories for the past $5 \mathrm{yr}$. Cultured cells were maintained in RPMI 1640 media supplemented with L-glutamine, $25 \mathrm{mM}$ Hepes, $10 \%$ fetal bovine serum, 10,000 U/ml penicillin, and $100 \mu \mathrm{g} / \mathrm{ml}$ streptomycin and passed when the cells attained confluency. Subcultures (MNB-T2) were initiated at a density of $1 \times 10^{6}$ cells per $75 \mathrm{~cm}^{2}$ flask containing $75 \mathrm{ml}$ of media and harvested at confluency. Primary cultures (MNB-T1) were also established by subculturing $2 \times 10^{6}$ disaggregated cells obtained from in situ tumors. Tissue culture cells were harvested by agitating the flasks until all cells were dislodged from the bottom. Cell suspensions were counted in an eosinophil counting chamber and their viability determined by trypan blue dye exclusion. After centrifugation at $250 \mathrm{~g}$, cell pellets were washed twice with phosphate buffer, resuspended, and homogenized for $30 \mathrm{~s}$ at $4^{\circ} \mathrm{C}$ with the Polytron apparatus.

In situ growth of MNB-T1 and MNB-T2 cells. Two groups of male $\mathrm{A} / \mathrm{J}$ mice consisting of 25 animals each, were injected subcutaneously with $10^{6}$ cells harvested from MNB-T1 or MNB-T2 tissue cultures. Mice were examined daily for tumor growth by measuring the length and width of each tumor. $14 \mathrm{~d}$ after MNB implantation five mice with palpable tumors were killed from each group. MNB tumors were excised and DPD activity and catecholamine concentration determined. The remaining mice were examined daily either until death or spontaneous resolution of the tumors.

Preparation of enzyme supernatants. Cytosolic preparations of liver, brain, tumor tissue and cultured MNB cells were obtained by ultracentrifugation at $105,000 \mathrm{~g}$ for $1 \mathrm{~h}$ at $4^{\circ} \mathrm{C}$. The supernatant fluid was carefully decanted (to avoid the lipid layer) and protein concentration determined by the Lowry method (6). Enzyme activity was generally assayed on the day of tissue harvest; however, enzyme activity remained stable for $1 \mathrm{wk}$ at $4^{\circ} \mathrm{C}$ and for several months at $-80^{\circ} \mathrm{C}$.

Assay of enzyme activity. Cytosolic preparations were incubated with $\left[2-{ }^{14} \mathrm{C}\right]$ thymine in the presence of various concentrations of NADPH. The reaction mixture contained $0.5-1.0 \mathrm{mg}$ cell supernatant protein, $25 \mu \mathrm{M}\left[2-{ }^{14} \mathrm{C}\right]$ thymine, $35 \mathrm{mM}$ phosphate buffer, $\mathrm{pH} 7.4,2.5$ $\mathrm{mM} \mathrm{MgCl}_{2}$ and NADPH at the following concentrations: $0.1,0.25$, $0.5,1.0,2.5$, and $5.0 \mathrm{mM}$. After establishing the optimal NADPH concentration requirement, $2.5 \mathrm{mM}$ NADPH was used in all subsequent experiments. ${ }^{2}$ The DPD activity of cultured cell supernates was assayed in $1.5 \mathrm{ml}$ conical, capped tubes in a total volume of $200 \mu \mathrm{l}$. Tissue supernates were assayed in a total volume of $0.5 \mathrm{ml}$ using a 25-ml erlenmeyer flask containing a suspended center well that held a glass fiber paper saturated with $100 \mu \mathrm{l}$ hyamine hydroxide. The reaction mixture was incubated at $37^{\circ} \mathrm{C}$ for $15 \mathrm{~min}$ for liver, and $3 \mathrm{~h}$ for brain, tumor, and cell supernates. The reaction was stopped by addition of $50 \mu \mathrm{l}$ of $10 \%$ perchloric acid (flasks) or by immersion for $1 \mathrm{~min}$ in a boiling water bath (tubes). All samples were frozen $\left(-20^{\circ} \mathrm{C}\right)$ until HPLC analysis. Before the chromatographic separation, the denatured protein was removed by centrifugation and the supernatant fluid passed through a 0.2- $\mu \mathrm{m}$ filter (Acro LC 13; Gelman Sciences, Ann Arbor, MI). A 20- $\mu$ l aliquot of each sample, corresponding to $0.5 \mathrm{nmol}$ of $\left[2-{ }^{14} \mathrm{C}\right]$ thymine $\left(60 \times 10^{3} \mathrm{dpm}\right)$, was injected into the HPLC.

HPLC separation. The substrate, $\left[2-{ }^{14} \mathrm{C}\right]$ thymine and products, $\left[2-{ }^{14} \mathrm{C}\right]$ dihydrothymine and $\left[5-{ }^{14} \mathrm{C}\right]$ ureidoisobutyrate, were separated using a Hewlett-Packard 1090 HPLC (1090; Hewlett Packard Co., Palo Alto, CA) with a photodiode array detector, DPU integration package and $85 \mathrm{~B}$ microcomputer as the system controller. Separation was by reverse-phase chromatography using a $C_{18}$ analytical cartridge column $(4.6 \times 150 \mathrm{~mm} ; 3 \mu \mathrm{m}$ particles $)$ and equipped with a $4.6 \times 10$ mm guard cartridge (Econosphere; Alltech Associates, Inc., Deerfield, IL). The mobile phase was $0.02 \mathrm{M}$ monobasic phosphate (Ultrex grade; J.T. Baker Chemical Co., Phillipsburg, NJ), pH 5.6 with an acetonitrile gradient of $0.2 \% / \mathrm{min}$ for the first $5 \mathrm{~min}$ and $0.8 \% / \mathrm{min}$ for the next 5 min to a final concentration of $5 \%$. The flow rate was $0.75 \mathrm{ml} / \mathrm{min}$. Standard solutions of thymine, dihydrothymine, and ureidoisobutyrate in distilled $\mathrm{H}_{2} \mathrm{O}$ were injected to determine the retention times of all compounds. A typical chromatographic separation profile is shown in Fig. 2. Thymine, which possesses a double bond, has a characteristic

2. In the initial phase of this study $200 \mu \mathrm{M}$ NADPH was employed in the DPD reaction mixture that also contained $5 \mathrm{mM} 2 \mathrm{ME}$. Under those conditions, that had been considered optimal for the assay of DPD in rat liver supernatant (7), little DPD activity was detected $(\sim 20 \mathrm{pmol} / \mathrm{mg}$ protein per $\mathrm{h}$ ) in cytosol prepared from cultured MNB cells (MNB-T2). DPD activity in the MNB cells could be easily detected however, if higher concentrations of NADPH were employed. The requirement of higher NADPH concentrations was found to be related to the presence of $2 \mathrm{ME}$ in phosphate buffer when it was stored for longer than a few days. The absence of $2 \mathrm{ME}$ in the stored buffer or, alternatively, addition of fresh $2 \mathrm{ME}$ directly to an inactive reaction mixture resulted in the marked restoration of DPD activity even in the presence of low NADPH concentrations $(0.05 \mathrm{mM})$. However, at NADPH concentrations of greater than $2.5 \mathrm{mM}$, maximal DPD activity $\left(V_{\max }\right)$ observed was independent of $2 \mathrm{ME}$ concentration (see Fig. 4). 


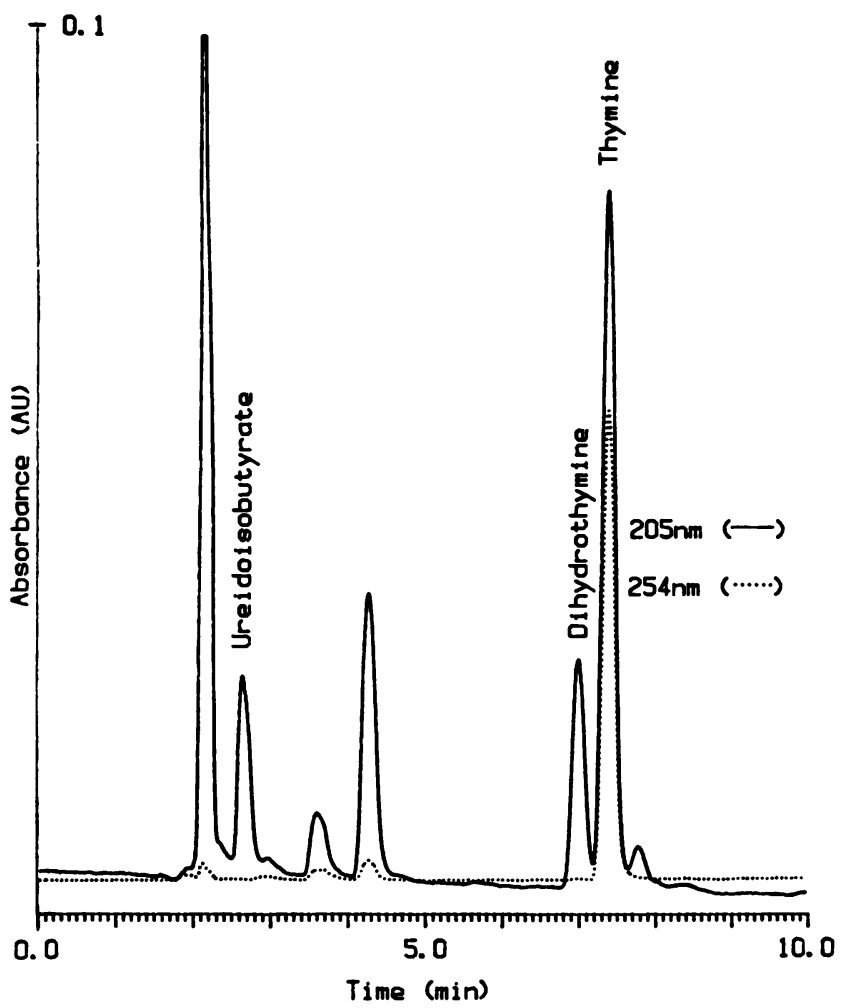

Figure 2. High performance liquid chromatographic separation of ureidoisobutyrate, dihydrothymine and thymine standards. A diode array detector was used for simultaneous, dual wavelength monitoring. Ureidoisobutyrate and dihydrothymine absorb only at $205 \mathrm{~nm}$, while thymine also absorbs at the 254-nm wavelength. Chromatographic conditions: mobile phase $=0.02 \mathrm{M} \mathrm{KH}_{2} \mathrm{PO}_{4}, \mathrm{pH} \mathrm{5.6}$, flow rate $=0.75 \mathrm{ml} / \mathrm{min}$, gradient (acetonitrile) $=0.2 \% / \mathrm{min} \times 5 \mathrm{~min}$, $0.8 \% / \mathrm{min} \times 5 \mathrm{~min}$. Retention times: ureidoisobutyric, 2.8 ; dihydrothymine, 7.0; and thymine, $7.4 \mathrm{~min}$. Postrun washing of the column with a high percentage of acetonitrile $(>20 \%)$ resulted in obstruction of the column and was avoided.

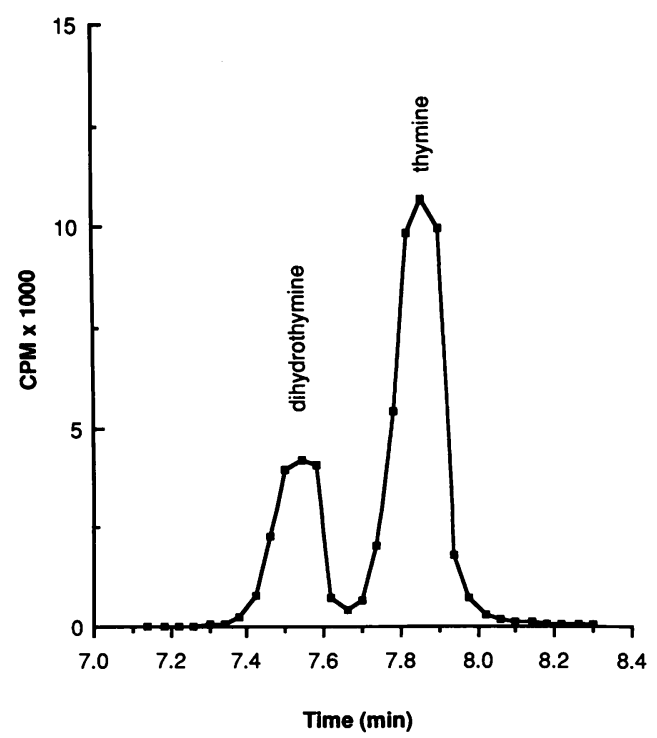

Figure 3. Reconstruction of the chromatographic separation of radiolabeled dihydrothymine and thymine. Radioactive $\left({ }^{14} \mathrm{C}\right)$ fractions of 0.04 min duration were collected from an experimental sample and the radioactivity determined as described in Methods. ultraviolet spectrum with peak absorption maxima at 205 and $254 \mathrm{~nm}$, whereas dihydrothymine and ureidoisobutyrate show an absorption maximum only at $205 \mathrm{~nm}$. As demonstrated in Fig. 2, the difference in retention times between thymine and dihydrothymine was very short $(0.3 \mathrm{~min})$. Therefore, it was necessary to collect small fractions $(0.04$ $\min ; \sim 30 \mu$ l) to facilitate the uncontaminated separation of labeled thymine and its dihydrothymine metabolite (Fig. 3). The substrate and product peaks were collected directly into scintillation vials containing $3.5 \mathrm{ml}$ scintillation fluid (Safety-Solv; Research Products International, Mt. Prospect, IL) using a fraction collector (FRAC 100 Pharmacia; Pharmacia Fine Chemicals, Piscataway, NJ). The activity of ureidopropionase (UP) was assayed by determining the quantity of ${ }^{14} \mathrm{CO}_{2}$ released during the reaction. The ${ }^{14} \mathrm{C}$ present in the collected fractions and in the hyamine hydroxide-soaked filters was counted by a liquid scintillation counter (LS 7500; Beckman Instruments, Inc., Fullerton, CA). The specific activity of each enzyme was calculated from the amount of product formed and expressed as picomoles per milligram protein per hour. The lower limit of detection of DPD activity with this method was $15 \mathrm{pmol} / \mathrm{mg}$ per $\mathrm{h}$.

Tissue catecholamines. Determinations of norepinephrine, epinephrine, and dopamine content in MNB-T1 and MNB-T2 tumors was performed by HPLC coupled to an electrochemical detector as previously described (8).

\section{Results}

Activity of pyrimidine degrading enzymes in liver, brain, and murine neuroblastoma. Fig. 4 illustrates the relationship between the concentration of NADPH and the specific activity of DPD in the presence and absence of $2 \mathrm{ME}^{2}$ The apparent $K_{\mathrm{m}}$ value for NADPH in both MNB cell line supernates was

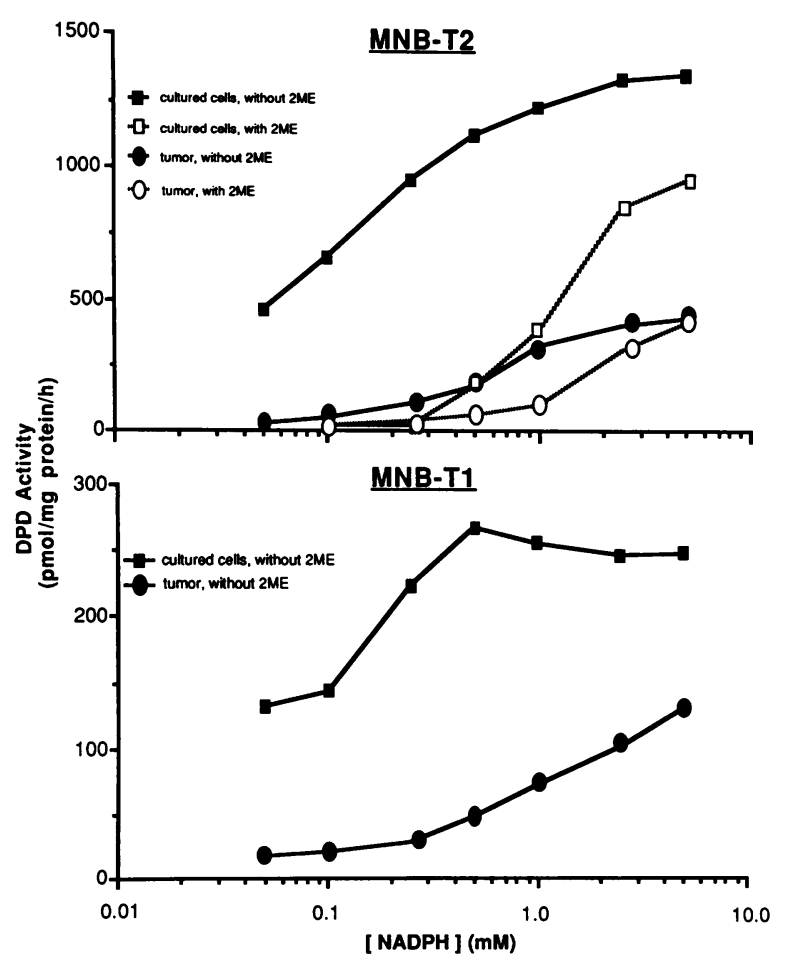

Figure 4. Effect of NADPH concentration on DPD activity in supernates prepared from cultured MNB-T1 (high malignancy line) and MNB-T2 (low malignancy line) cells and their respective tumors. Activity of DPD in MNB-T2 cells and tumors is significantly higher than in MNB-T1. The presence of $2 \mathrm{ME}$ in stored phosphate buffer resulted in suppression of DPD activity which could be recovered employing higher concentrations of NADPH. 
Table I. DPD Activity in Supernatant Fluid Prepared from In Situ Murine Neuroblastoma Tumors and Cultured Cells

\begin{tabular}{|c|c|c|c|c|c|}
\hline & \multicolumn{2}{|c|}{ MNB-T2* (low malignancy) } & \multicolumn{2}{|c|}{ MNB-T1 $1^{\ddagger}$ (high malignancy) } & \multirow[b]{2}{*}{$P$} \\
\hline & Mean \pm SEM & $N^{8}$ & Mean \pm SEM & $N$ & \\
\hline \multicolumn{6}{|l|}{ Cultured cells } \\
\hline ( $\mu \mathrm{g} \mathrm{pr.} / 10^{6}$ cells $)$ & $36.4 \pm 5.47$ & (11) & $37.3 \pm 3.11$ & (12) & $>0.05$ \\
\hline Sp act & $1,846.9 \pm 237.3$ & (6) & $264.4 \pm 10.8$ & (4) & $<0.001$ \\
\hline \multicolumn{6}{|l|}{ In situ tumors } \\
\hline mg pr./gwt. & $32.3 \pm 4.12$ & (4) & $34.8 \pm 4.22$ & $(5)$ & $>0.05$ \\
\hline Sp act & $513.3 \pm 71.6$ & (6) & $129.4 \pm 11.2$ & (7) & $<0.0001$ \\
\hline
\end{tabular}

DPD specific activity is expressed as picomoles DHT generated per milligram supernatant protein (pr.) per hour. The basic reaction mixture contained $25 \mu \mathrm{M}\left[2 .{ }^{14} \mathrm{C}\right]$ thymine, $2.5 \mathrm{mM}$ NADPH, and $0.5 \mathrm{mg}$ supernatant protein and was incubated for $3 \mathrm{~h}$ at $37^{\circ} \mathrm{C}$. Control mixtures were identical to the reaction mixtures but were stopped at time 0 and showed no DPD activity. ${ }^{*}$ Murine neuroblastoma cells after long-term passage in culture. ${ }^{\ddagger}$ Murine neuroblastoma cultured cells derived from spontaneous, long-term passaged in situ tumor. ${ }^{\S}$ Number of assays done in duplicate on separate passages.

$\sim 0.08 \mathrm{mM}$. The presence of $2 \mathrm{ME}$ in the stored buffer shifted the response curve to the right without significantly affecting the $V_{\max }$.

Neither $\left[5-{ }^{14} \mathrm{C}\right]$ ureidoisobutyrate nor ${ }^{14} \mathrm{CO}_{2}$ was produced by supernatant fluid obtained from either MNB-T1 or MNB-T2 cells, MNB tumors or murine brain, indicating the apparent absences of dihydropyrimidine amidohydrolase (DAH) and UP activity in these tissues. Mouse liver cytosol possessed abundant activity of all three pyrimidine degradative enzymes as indicated by the virtually complete conversion of $\left[2-{ }^{14} \mathrm{C}\right]$ thymine to ${ }^{14} \mathrm{CO}_{2}$. Approximately $0.5 \%$ of the $\left[2-{ }^{14} \mathrm{C}\right]$ thymine present in the incubation mixture was detected as $\left[2-{ }^{14} \mathrm{C}\right]$ dihydrothymine and none as $\left[5-{ }^{14} \mathrm{C}\right]$ ureidoisobutyrate (data not shown). The affinity of DPD for NADPH in mouse liver was similar $\left(K_{\mathrm{m}} \sim 0.08 \mathrm{mM}\right)$ to that of brain, MNB-T1 and MNB-T2 cells.

In situ tumor growth, DPD activity and catecholamine concentration of $M N B-T 1$ and $M N B-T 2$ cell lines. A comparison of DPD activity in MNB-T1 and MNB-T2 cultured cells and their respective in situ tumors is shown in Table I. DPD activity was significantly lower in MNB-T1 cultured cells and tumor tissue derived from implanted MNB-T1 cells when compared to the enzyme activity of MNB-T2 cultured cells and their respective in situ tumors. Host survival, presence of tumors, tumor catecholamine concentration and DPD activity following the injection of cultured MNB-T1 and MNB-T2 cells into two groups of mice are summarized in Table II. The specific activity of DPD in tumors derived from injected MNB-T 1 cells was similar to that found in the parent MNB-T1 cultured cell line. This activity was significantly lower than that of MNB-T2 cells and tumors derived from this line $(P$ $<0.001)$. Tumors derived from the MNB-T1 cell line contained less norepinephrine and dopamine than tumors derived from the MNB-T2, but the differences were not statistically significant $(P>0.05)$. Trace amounts of epinephrine were detected in both tumor types. $32 \%$ of the mice injected with MNB-T2 cells did not develop tumors and those that did showed a significantly slower tumor growth rate (Fig. 5) and reduced mortality (Fig. 6) when compared to mice implanted with MNB-T1 cells.

\section{Discussion}

The relationship between pyrimidine base metabolism by dihydropyrimidine dehydrogenase (E.C. 1.3.1.2) and neoplastic expression in MNB cells has been investigated. This investiga-

Table II. Comparison of DPD Activity in MNB Tumors and Correlation to Biologic Behavior

\begin{tabular}{|c|c|c|c|c|c|c|}
\hline \multirow[b]{2}{*}{ Parameter } & \multicolumn{3}{|c|}{ MNB-T2 (low malignancy) } & \multicolumn{3}{|c|}{ MNB-T1 (high malignancy) } \\
\hline & Mean & \pm SEM & $n$ & Mean & \pm SEM & $n$ \\
\hline DPD activity & 597.7 & 79.8 & (4) & 106.0 & 19.01 & (5) \\
\hline \multicolumn{7}{|l|}{ Catecholamine levels* } \\
\hline Epinephrine & Trace & - & (4) & Trace & - & (5) \\
\hline Norepinephrine & 50.59 & 24.23 & (4) & 12.85 & 2.18 & (5) \\
\hline \multirow[t]{2}{*}{ Dopamine } & 12.45 & 4.52 & (4) & 7.89 & 2.62 & (5) \\
\hline & \multicolumn{3}{|l|}{$n / n(\%)$} & \multicolumn{3}{|l|}{$n / n(\%)$} \\
\hline Number of tumors developed ${ }^{\ddagger}$ & \multicolumn{3}{|c|}{$17 / 25(68 \%)$} & \multicolumn{3}{|c|}{$24 / 24(100 \%)$} \\
\hline Mortality (\%) & \multicolumn{3}{|c|}{$4 / 20(20 \%)$} & \multicolumn{3}{|c|}{$19 / 19(100 \%)$} \\
\hline Number of tumors regressed ${ }^{\S}$ & \multicolumn{3}{|c|}{$8 / 12(75 \%)$} & \multicolumn{3}{|c|}{$0 / 19(0 \%)$} \\
\hline
\end{tabular}

* Catecholamine levels in $\mu \mathrm{g} / \mathrm{g}$ tumor wet weight. ${ }^{\ddagger}$ Observations up to $60 \mathrm{~d}$ after injection, five animals per group were sacrificed at day 14 following injection for studies on tumor tissue. One mouse injected with MNB-T1 cells died $2 \mathrm{~d}$ after injection and was not included. ${ }^{\S}$ Tumor formed but regressed with time. 


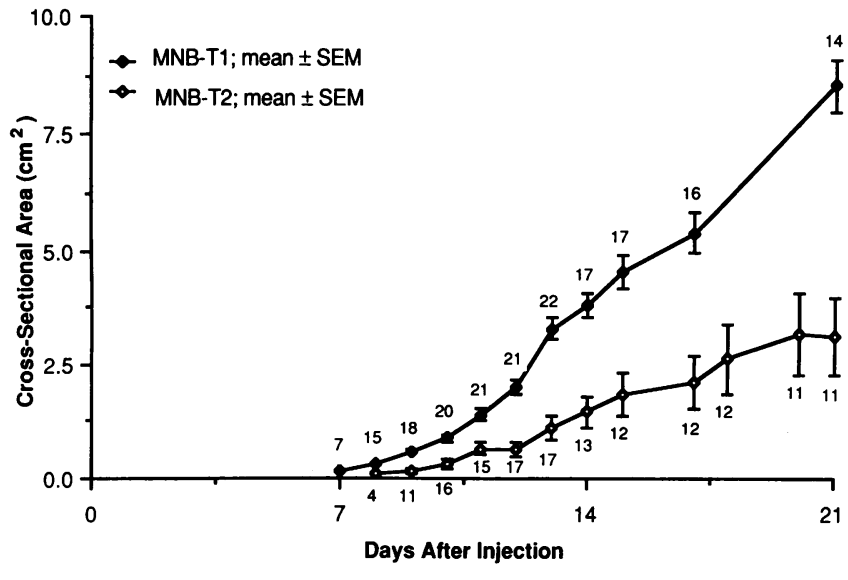

Figure 5. Comparison of tumor growth rates in mice injected with MNB-T1 (high malignancy line) and MNB-T2 (low malignancy line) cells. Two groups of 25 mice each were injected subcutaneously with a $0.2 \mathrm{ml}$ suspension $\left(1 \times 10^{6}\right.$ cells) prepared from MNB-T1 and MNB-T2 tissue cultures, respectively. Tumors were initially palpated and measured at $7 \mathrm{~d}$ after injection. Mean \pm SEM of cross-sectional tumor areas are plotted for the number of tumors shown at each point. Cross-sectional areas for MNB-T1 tumors were significantly larger than those of MNB-T2 tumors $(P<0.01)$ from day 9 and on.

tion has demonstrated significant differences in the DPD activity of two MNB cell lines carried in tissue culture and in situ.

The pyrimidine bases, uracil and thymine, are degraded to $\beta$-alanine and $\beta$-aminoisobutyrate by three sequential enzymes $(9,10)$ (Fig. 1). Initially the pyrimidine ring is reversibly reduced at positions 5,6 in the presence of the cofactor NADPH. This reaction is catalyzed by the enzyme DPD, which is considered to be rate limiting in the degradation of pyrimidine bases $(11,12)$. The dihydopyrimidine rings are subsequently cleaved by dihydropyrimidine amidohydrolase (E.C. 3.5.2.2) to form $\beta$-ureidopropionate and $\beta$-ureidoisobutyrate, respectively (13). The final reaction, catalyzed by ureidopropionase (E.C. 3.5.1.6) converts $\beta$-ureidopropionate and $\beta$-ureidoisobutyrate into $\beta$-alanine and $\beta$-aminoisobutyrate, respectively, releasing ammonia and $\mathrm{CO}_{2}(14)$.

In the present investigation, DAH and UP activity was detected primarily in mouse liver, whereas no measurable activity was observed in brain. DAH and UP activity was not

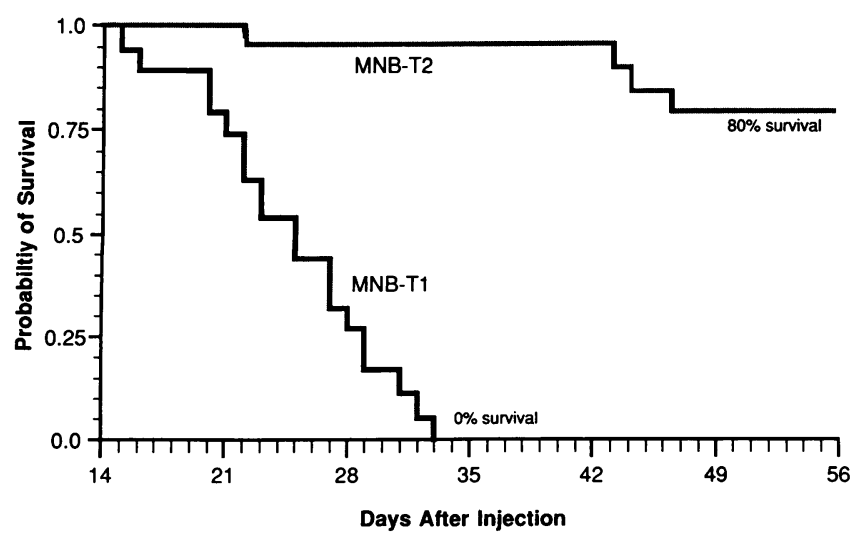

Figure 6. Survival curves for A/J mice injected with MNB-T1(high malignancy line) or MNB-T2 (low malignancy line) cells. measurable in cytosol prepared from MNB cells, a phenomenon also observed by us in skin fibroblasts, white blood cells and platelets (data not shown). Naguib et al. (4) found DAH activity in human solid tumors but not in their normal tissue of origin. The biological significance of this phenomenon, as well as the presence of only the first enzymatic step in pyrimidine degradation in some tissues is unclear.

As has been suggested by other investigators, this study supports the hypothesis that the rate limiting enzyme for thymine degradation in mouse liver is DPD. This conclusion is based on the observation that no ureidoisobutyrate and only very small amounts of dihydrothymine were detected following the incubation of mouse liver cytosol with thymine. DPD present in cultured MNB cells has an affinity for NADPH that is similar to that of mouse liver and brain, suggesting the existence of identical or similar DPD proteins in these tissues.

Very low DPD activity was detected in MNB tumors maintained in situ and in tissue culture derived from them (MNB-T1). In comparison, MNB cells carried in tissue culture for more than 100 generations and tumors derived from these cells (MNB-T2) had high DPD activity (Table I). The DPD activity of MNB-T1 and MNB-T2 lines in culture and in situ inversely correlated with their tumorgenicity following implantation into $\mathrm{A} / \mathrm{J}$ mice. These findings may reflect differing synthesis of DPD protein in MNB cell lines. Possibly, MNB-T2 cultured cells may have undergone spontaneous mutations resulting in the enhancement of DPD synthesis. Furthermore, the content of norepinephrine and dopamine was similar in both tumor lines, suggesting a parallel expression of neural crest characteristics which did not correlate with either DPD activity or malignant behavior. An increase in DPD activity in MNB-T2 cells associated with a decrease in malignant potential is compatible with the observations of Weber et al. who reported decreased DPD activity in hepatoma cells when compared to normal liver cells $(15,16)$.

It has been suggested by Smith and Yamada that soluble cytosolic DPD is an anabolic rather than a catabolic enzyme and its affinity for oxidized NADP ${ }^{+}$is much higher than that for reduced $\mathrm{NADP}^{+}$(17). This difference in affinity would facilitate the conversion of dihydropyrimidines to pyrimidines with their subsequent incorporation into nucleic acids. The present study, however, does not support this viewpoint since DPD activity was highest in the MNB-T2 cell line that expressed the lower malignant potential.

A variety of analytical methods have been employed to measure pyrimidine base degradative enzyme activity in tissues. The spectrophotometric methods for DPD is adequate for tissues with high enzymatic activity, but not sensitive enough for tissues with low enzymatic activities. The utilization of radiolabeled substrates coupled to the separation of substrate and products by TLC is considerably more sensitive (18), however this chromatographic technique is much less efficient than HPLC. In this investigation, we have used radiolabeled thymine as the substrate, as opposed to radiolabeled uracil which was previously employed in the TLC method. Thymine is less polar, and hence retained longer on reverse phase chromatographic columns, thus, improving the separation of the substrate from its product (Fig. 2). Collection of small eluate fractions ( $30 \mu \mathrm{l} / 0.04 \mathrm{~min}$ ) permitted the identification and quantitation of radiolabeled substrate and product (Fig. 3). This sensitive method may open the door to important new investigations of pyrimidine degradative enzymes in human tissues with low enzymatic activity. 
In conclusion, our results suggest that the MNB cell system provides a useful model for further investigation of the control mechanisms regulating pyrimidine degradative activity in cancer cells.

\section{Acknowledgments}

This work was supported in part with grants from the U. S. Public Health Service (NS-17194), the Minnesota Medical Foundation and from the Vikings Children's Research Fund.

\section{References}

1. Ferdinandus, J. A., H. P. Morris, and G. Weber. 1971. Behavior of opposing pathways of thymidine utilization in differentiating, regenerating and neoplastic liver. Cancer Res. 31:550-556.

2. Wasternack, C. 1980. Degradation of pyrimidines and pyrimidine analogs-pathways and mutual influences. Pharmacol. Ther. 8:629-651.

3. Weber, G., and M. A. Lea. 1967. The molecular correlation concept: An experimental and conceptual method in cancer research. In Methods in Cancer Research. Vol. 2. H. Busch, editor. Academic Press, Inc., New York. 523-578.

4. Naguib, F. N. M., M. H. el Kouni, and S. Cha. 1985. Enzymes of uracil catabolism in normal and neoplastic human tissues. Cancer Res. 45:5405-5412.

5. Tuchman, M., M. L. R. Ramnaraine, and R. F. O'Dea. 1985. Effects of uridine and thymidine on the degradation of 5-fluorouracil, uracil and thymine by rat liver dihydropyrimidine dehydrogenase. Cancer Res. 45:5553-5556.

6. Lowry, O. H., N. J. Rosebrough, A. L. Farr, and R. J. Randall. 1951. Protein measurement with the Folin phenol reagent. J. Biol. Chem. 193:265-275.
7. Shiotani, T., and G. Weber. 1981. Purification and properties of dihydrothymine dehydrogenase from rat liver. J. Biol. Chem. 256:219-224.

8. Pons, G., R. F. O’Dea, and B. L. Mirkin. 1982. Biological characterization of the C-1300 murine neuroblastoma: An in vivo neural crest tumor model. Cancer Res. 42:3719-3723.

9. Fink, R. M., K. Fink, and R. B. Henderson. 1953. $\beta$-Amino acid formation by tissue slices incubated with pyrimidines. J. Biol. Chem. 201:349-355.

10. Canellakis, E. S. 1956. Pyrimidine metabolism. I. Enzymatic pathways of uracil and thymine degradation. J. Biol. Chem. 221:315322.

11. Grisolia, S., and S. S. Cardoso. 1957. The purification and properties of hydro-pyrimidine dehydrogenase. Biochim. Biophys. Acta. 25:430-431.

12. Fritzson, P. 1960. Properties and assay of dihydrouracil dehydrogenase of rat liver. J. Biol. Chem. 235:719-725.

13. Wallach, D. P., and S. Grisolia. 1957. The purification and properties of hydropyrimidine hydrase. J. Biol. Chem. 226:277-288.

14. Caravaca, J., and S. Grisolia. 1958. Enzymatic decarbamylation of carbamyl $\beta$-alanine and carbamyl $\beta$-aminoisobutyric acid. $J$. Biol. Chem. 231:357-365.

15. Queener, S. F., H. P. Morris, and G. Weber. 1971. Dihydrouracil dehydrogenase activity in normal, differentiating, and regenerating liver and hepatomas. Cancer Res. 31:1004-1009.

16. Weber, G., E. Olah, J. E. Denton, M. S. Lui, E. Takeda, D. Y. Tzeng, and J. Ban. 1981. Dynamics of modulation of biochemical programs in cancer cells. Adv. Enzyme Regul. 19:87-102.

17. Smith, A. E., and E. W. Yamada. 1971. Dihydrouracil dehydrogenase of rat liver. Separation of hydrogenase and dehydrogenase activities. J. Biol. Chem. 246:3610-3617.

18. Traut, T. W., and S. Loechel. 1984. Pyrimidine catabolism: Individual characterization of the three sequential enzymes with a new assay. Biochemistry. 23:2533-2539. 